\title{
Influence of Various Forms of Foliar Application on Root Yield and Technological Quality of Sugar Beet
}

\author{
Arkadiusz Artyszak*(D) and Dariusz Gozdowski \\ Institute of Agriculture, Warsaw University of Life Sciences-SGGW, Nowoursynowska 159, 02-776 Warsaw, \\ Poland; dariusz_gozdowski@sggw.edu.pl \\ * Correspondence: arkadiusz_artyszak@sggw.edu.pl; Tel.: +48-22-593-2702
}

check for updates

Citation: Artyszak, A.; Gozdowski, D. Influence of Various Forms of Foliar Application on Root Yield and Technological Quality of Sugar Beet. Agriculture 2021, 11, 693. https:// doi.org/10.3390/agriculture11080693

Academic Editors: William A. Payne and Lorenzo Barbanti

Received: 14 June 2021

Accepted: 22 July 2021

Published: 23 July 2021

Publisher's Note: MDPI stays neutral with regard to jurisdictional claims in published maps and institutional affiliations.

Copyright: (c) 2021 by the authors. Licensee MDPI, Basel, Switzerland. This article is an open access article distributed under the terms and conditions of the Creative Commons Attribution (CC BY) license (https:// creativecommons.org/licenses/by/ $4.0 /)$.

\begin{abstract}
The Green Deal adopted by the European Commission assumes a significant reduction in the use of pesticides and synthetic fertilizers. It is necessary to search for environmentally safe technologies that will prevent a reduction in crop yield. One of such methods, which was examined in the study, is the foliar application of silicon, which can have a positive effect on root yield and its quality. In the period 2017-2019, a field experiment was carried out in which the effectiveness of the application of various forms of silicon (orthosilicic acid, a mixture of orthosilicic and polysilicic acid and calcium silicate) in sugar beet cultivation was assessed. The applied treatments of foliar application increased the root yield by $10.7-11.7 \%$, the biological sugar yield by $8.4-12 \%$ and the pure sugar yield by $7.2-11.8 \%$ as compared to the control treatment. The differences between the individual treatments in terms of these characteristics were insignificant. Their impacts on the technological quality of roots (content of sugar, $\alpha$-amino nitrogen, potassium and sodium) were different.
\end{abstract}

Keywords: foliar fertilization; Beta vulgaris; orthosilicic acid; silica nanoparticles; calcium silicate

\section{Introduction}

Sugar beet is the main raw material for sugar production in Europe. In 2019, it covered an area of 1.64 million ha in the European Union (28 countries) [1]. The production of sugar beet is limited by abiotic and biotic stress factors. The "farm to fork" strategy adopted by the European Commission assumes a significant limitation of the use of plant protection products and mineral fertilizers [2]. In order to prevent a reduction in sugar beet production, it is necessary to search for modern and environmentally safe production methods. An innovative method to limit their impact on sugar yields is the foliar application of products containing silicon (Si) [3]. This treatment primarily increases the tolerance of plant to water stress. It contributes to the growth of the root yield and usually does not significantly affect the technological quality of the roots, which in turn increases the biological yield of sugar and pure sugar yield.

It is commonly believed that the best effects are obtained with foliar silicon in the form of stabilized orthosilicic acid [4]. The research results show that good results in sugar beet production can be obtained by using marine calcite [5-8], a mixture of orthosilicic and polysilicic acids [4,8], potassium silicate [9] or silica nanoparticles [10,11].

The aim of the study is to assess the effectiveness of the foliar application of siliconcontaining products in the form of orthosilicic acid, a mixture of orthosilicic and polysilicic acid and calcium silicate on the root yield, technological quality, biological sugar yield and pure sugar yield and indicate which effect is the strongest for the studied traits.

The following research hypothesis was assumed: the foliar application of various forms of silicon in sugar beet cultivation has a diversified impact on the root yield, technological quality as well as the biological and pure yield of sugar. 


\section{Materials and Methods}

The experiment was conducted in 2017-2019 in the south-eastern region of Poland, in Sahryń $\left(50^{\circ} 41^{\prime} \mathrm{N}, 23^{\circ} 46^{\prime}\right.$ E). The soil type was Calcic Chernozem (Aric, Siltic) (silty clay loam: clay-34\%; sand-14\%; silt-52\%) [12].

The chemical analyses were conducted at District Chemical and Agricultural Stations in Warsaw, Wesoła. The soil's physico-chemical properties were evaluated using standard methods, i.e., $\mathrm{pH}_{\mathrm{KCl}}$ was measured potentiometrically in $1 \mathrm{M} \mathrm{KCl}$ [13]; oil organic carbon (SOC) was measured using Tiurin's method [14]; nitrate nitrogen $\left(\mathrm{N}-\mathrm{NO}_{3}\right)$ and ammonium nitrogen $\left(\mathrm{N}-N H_{4}\right)$ were extracted with $1 \%$ potassium sulphate and then measured with the use of the continuous flow analysis method [15]; phosphorus (P) was measured by the Egner-Riehm DL method [16]; potassium (K) was extracted with calcium lactate and measured by the flame photometry method [17]; magnesium $(\mathrm{Mg})$ was extracted with calcium chloride and evaluated by flame atomic absorption spectrometry [18]; boron (B) was measured with the use of the spectrophotometric method [19]; copper $(\mathrm{Cu})$ was extracted using hydrochloric acid and evaluated by flame atomic absorption spectrometry [20]; iron $(\mathrm{Fe})$ was extracted with hydrochloric acid and evaluated by flame atomic absorption spectrometry [21]; manganese (Mn) was extracted with hydrochloric acid and evaluated by flame atomic absorption spectrometry [22]; and zinc ( $\mathrm{Zn})$ was extracted with hydrochloric acid and evaluated by flame atomic absorption spectrometry [23].

The soil properties are presented in Table 1.

Table 1. Soil properties before sugar beet sowing in years 2016-2018.

\begin{tabular}{|c|c|c|c|c|c|c|c|c|c|c|c|c|}
\hline \multirow{2}{*}{ Location } & \multirow{2}{*}{$\mathrm{pH}_{\mathrm{KCl}}$} & \multirow{2}{*}{ SOC, \% } & \multicolumn{10}{|c|}{$\mathrm{mg} \mathrm{kg}^{-1}$} \\
\hline & & & $\mathrm{N}-\mathrm{NO}_{3}$ & $\mathrm{~N}-\mathrm{NH}_{4}$ & $\mathbf{P}$ & $\mathbf{K}$ & $\mathrm{Mg}$ & B & $\mathrm{Cu}$ & $\mathrm{Fe}$ & Mn & $\mathrm{Zn}$ \\
\hline 2016 & 7.3 & 2.11 & 81.5 & 5.02 & 46.2 & 104 & 71 & 2.8 & 6.4 & 540 & 164 & 6.3 \\
\hline 2017 & 7.5 & 1.66 & 36.2 & 1.58 & 86.8 & 62 & 69 & 2.2 & 7.3 & 490 & 167 & 5.9 \\
\hline 2018 & 7.3 & 2.76 & 18.4 & 3.11 & 90.7 & 133 & 99 & 5.6 & 8.8 & 630 & 157 & 8.0 \\
\hline
\end{tabular}

The amount of precipitation in the period from April to October in 2018 alone was higher than the multi-year average (Figure 1). The highest rainfall deficit in June occurred in 2017, in July in 2019 and in August in 2017-2018. In 2018, there was a higher average temperature in each month compared to the multi-year period; in 2017 it was June, AugustOctober; and in 2019, April, June-August and October.

After the rapeseed harvest, the straw was mixed with the soil with a stubble aggregate. This treatment was repeated twice more to destroy weeds and rape seed. Finally, a third tillage was also aimed for mixing phosphorus-potassium fertilizers with the soil. In autumn, Polifoska 6 fertilizer $(6 \% \mathrm{~N}$ in ammonium form, $8.7 \% \mathrm{P}$ as mono and diammonium phosphate, $24.9 \% \mathrm{~K}$ as potassium chloride and $2.8 \% \mathrm{~S}$ as sulphate) was applied at a dose of $400 \mathrm{~kg} \mathrm{ha}^{-1}$ and potassium chloride $\left(49.8 \%\right.$ of $\mathrm{K}$ ) at a dose of $300 \mathrm{~kg} \mathrm{ha}^{-1}$. In spring, Saletrzak Standard 27 with boron $(13.5 \% \mathrm{~N}$ in the ammonium form and $13.5 \% \mathrm{~N}$ in the nitrate form, $1.4 \% \mathrm{Ca}, 2.4 \% \mathrm{Mg}, 0.2 \% \mathrm{~B}$ ) was spread at the dose of $500 \mathrm{~kg} \mathrm{ha}^{-1}$ and immediately mixed with the soil using a tilling set. Overall, the following were applied to the soil in the experiment $\left(\mathrm{kg} \mathrm{ha}^{-1}\right)$ : $\mathrm{N}-159 ; \mathrm{P}-34.8 ; \mathrm{K}-249 ; \mathrm{S}-11.2 ; \mathrm{Ca}-7 ; \mathrm{Mg}-12$ and $\mathrm{B}-1$. Just before sowing, the soil was tilled shallowly with a cultivating unit.

Due to the varied course of spring weather, the sugar beet cultivar was sown at different times: in 2017, on 31 March; in 2018, on 11 April; and in 2019, on 30 March. The distances in the rows were $18 \mathrm{~cm}$, the row spacing was $45 \mathrm{~cm}$ and the sowing depth was 2$2.5 \mathrm{~cm}$. The Toleranza KWS variety was used in the experiment. Toleranza KWS (breeding company: KWS SAAT SE \& Co. (Einbeck, Germany)) is a diploid cultivar, normal type (N), which was entered into the Polish National Register in 2015. The cultivar is characterized by high yields of roots and sugar. The technological quality of roots is high; sugar content is slightly above the standard; $\alpha$-amino nitrogen content is quite low; potassium content is 
quite high; sodium content is quite low. Resistance to Cercospora beticola Sacc. is quite high. Resistance to beetroot nematode is declared by the breeder [24].

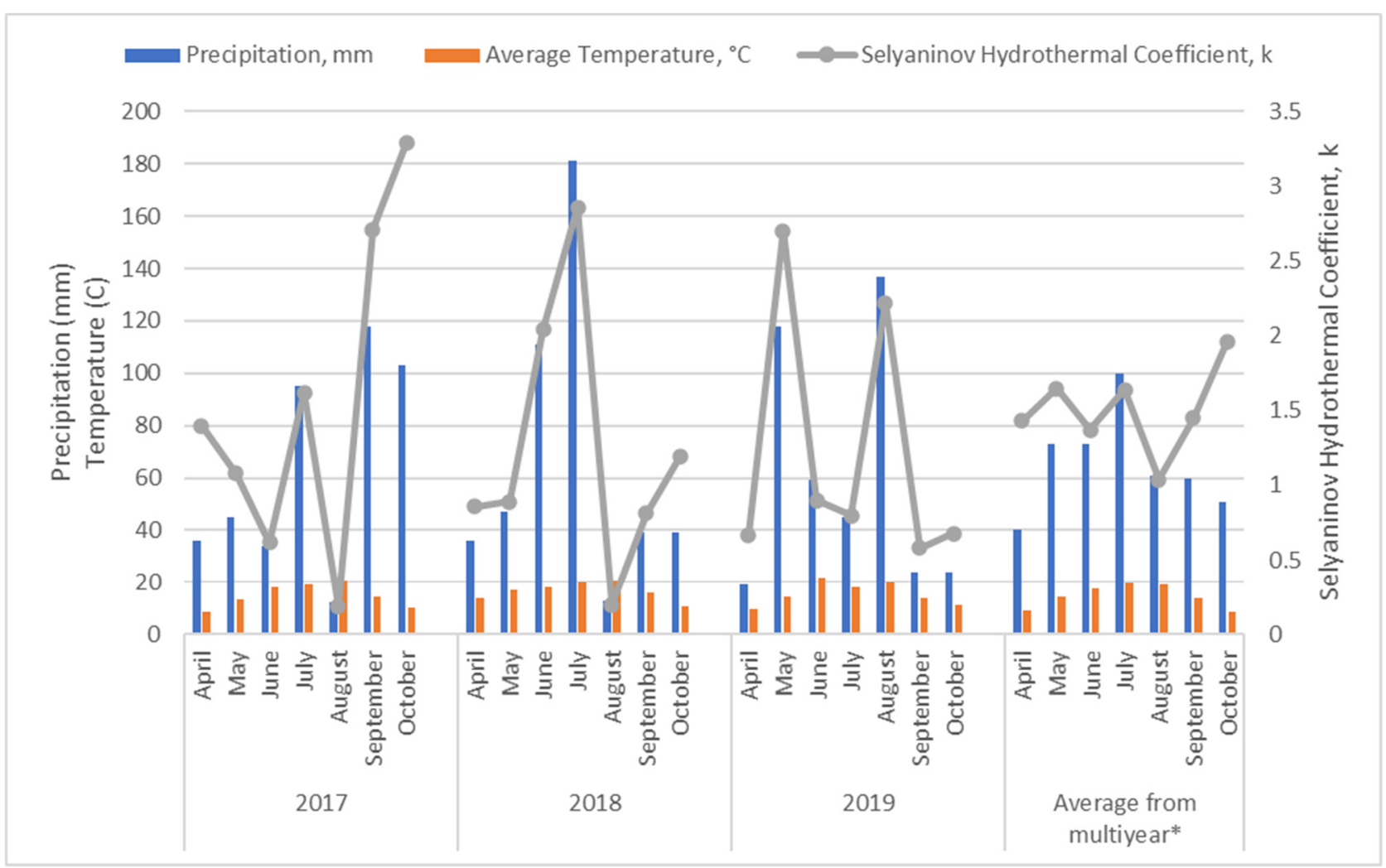

Figure 1. Temperature (in ${ }^{\circ} \mathrm{C}$ ), precipitation (in $\mathrm{mm}$ ) and Selyaninov Hydrothermal Coefficient during the growing season of sugar beet (2017-2019). * Precipitation: 1991-2019, Temperature: 2002-2019. Source: data from meteorological station located in Strzyżów Sugar Factory, geographical coordinates: 5050’30” N 2402'03” E.

The sugar beet was harvested on 12 October 2017; 6 October 2018; and 26 September 2019.

At the six-leaf stage of sugar beet (Biologische Bundesanstalt, Bundessortenamt und Chemical Industry growth scale-BBCH 16) and 14 days later, foliar nutrition was applied with micronutrient fertilizers containing boron $\left(2 \times 300 \mathrm{~g} \mathrm{ha}^{-1} \mathrm{~B}\right)$. Standard protection against weeds, diseases, and pests was performed in accordance with the recommendations of the Institute of Plant Protection-National Research Institute in Poznań.

Three silicon-containing products were used in the experiment: ZumSil $\left(88.1 \mathrm{~g} \mathrm{Si} \mathrm{L}^{-1}\right.$ in the form of orthosilicic acid, $\mathrm{pH}$ 9), Optysil (Si-94 $\mathrm{g} \mathrm{L}^{-1}$; Fe-24 $\mathrm{g} \mathrm{L}^{-1}$; a mixture of orthosilicic and polysilicic acid, neutral) and Barrier Si-Ca (calcium silicate; $\mathrm{SiO}_{2}-$ $336 \mathrm{~g} \mathrm{~L}^{-1} ; \mathrm{Ca}-207 \mathrm{~g} \mathrm{~L}^{-1} ; \mathrm{pH}$ 9.5-11.0) (Table 2). In each treatment, $250 \mathrm{~L}$ of water ha ${ }^{-1}$ was used. In variant no. 1 and 2 , the concentration of the working liquid was $0.2 \%$, and in variant no. 3 , it was $0.4 \%$.

Table 2. Treatments used in the experiment (2017-2019).

\begin{tabular}{cc}
\hline Treatment & Description \\
\hline $0-$ control & Without foliar application \\
1 & ZumSil $3 \times 0.5 \mathrm{~L} \mathrm{ha}^{-1}:$ at 6 leaves stage $(\mathrm{BBCH} 16)+7$ days later +14 days later \\
2 & Optysil $3 \times 0.5 \mathrm{~L} \mathrm{ha}^{-1}:$ at 6 leaves stage $(\mathrm{BBCH} 16)+7$ days later +14 days later \\
3 & Barrier Si-Ca $3 \times 1 \mathrm{~L} \mathrm{ha}^{-1}:$ at 6 leaves stage $(\mathrm{BBCH} 16)+7$ days later +14 days later \\
\hline
\end{tabular}


The foliar application was performed in 2017 on 27 May, 3 June and 10 June; in 2018 on 22 May, 29 May and 5 June; and in 2019 on 25 May, 31 May and 8 June. Spraying was performed with an Apollo trailed sprayer (Krukowiak).

Four replications for each treatment were conducted, i.e., 16 plots in each season (4 plots $\times 4$ treatments). Each individual plot had area of $43.2 \mathrm{~m}^{2}$ (16 m of length and $2.7 \mathrm{~m}$ of width) consisting of six rows of plants. Three middle rows were used for the harvesting and evaluation of yield. During harvest, the plants were topped by hand on the three middle rows, and the leaves were weighed. The roots were then counted, dug up and weighed. At harvest, each plot was treated in accordance with the Polish Standard [25]. The technological quality of the roots was evaluated on the automatic Venema technological line in the Kutno Sugar Beet Breeding Company in Straszków Poland [26]: the sugar content polarimetrically [27], the $\mathrm{K}$ and $\mathrm{Na}$ by photoelectric flame photometry [27] and the $\alpha$-amino nitrogen by fluorometric methods [28].

The measurements performed in the experiments were as follows: plant density at harvest (thousand plants ha $\left.{ }^{-1}\right)$; root yield $\left(\mathrm{t} \mathrm{ha} \mathrm{a}^{-1}\right)$; yield of leaves $\left(\mathrm{t} \mathrm{ha} \mathrm{a}^{-1}\right)$; yield of fresh biomass $\left(\mathrm{t} \mathrm{ha} \mathrm{a}^{-1}\right)$ as a sum of the root yield $\left(\mathrm{t} \mathrm{ha} \mathrm{a}^{-1}\right)$ and yield of leaves $\left(\mathrm{t} \mathrm{ha} \mathrm{a}^{-1}\right)$; harvest index (HI) as a ratio of root yield to fresh biomass; foliage coefficient as a ratio of yield of leaves to root yield; fresh biomass of root $(\mathrm{kg})$ as a ratio of root yield $(\mathrm{kg})$ and number of plants per plot at harvest; fresh biomass of leaves per plant $(\mathrm{kg})$ as a ratio of $(\mathrm{kg})$ and number of plants per plot at harvest; plant fresh weight $(\mathrm{kg})$ as the sum of fresh root mass $(\mathrm{kg})$ and leaves of a single plant $(\mathrm{kg})$; content of sucrose in roots $(\%)$; content of $\alpha$-amino nitrogen in the roots $(\mathrm{mmol} \mathrm{kg}-1)$; content of potassium $(\mathrm{K})$ in the roots $\left(\mathrm{mmol} \mathrm{kg}^{-1}\right)$; content of sodium $(\mathrm{Na})$ in the roots $\left(\mathrm{mmol} \mathrm{kg}^{-1}\right)$; biological yield of sugar $\left(\mathrm{t} \mathrm{ha}^{-1}\right)=$ product of root yield $\left(\mathrm{t} \mathrm{ha}^{-1}\right)$ and content of sugar in roots $(\%)$; pure sugar yield $\left(\mathrm{t} \mathrm{ha}^{-1}\right)=$ root yield $\left(\mathrm{t} \mathrm{ha}^{-1}\right)$ $\times$ [content of sugar (\%)—sugar yield losses (\%)] [29]; sugar yield losses (\%) = standard molasses losses $(\%)+0.6(\%)$ [29]; standard molasses losses $(\%)=0.012 \times(\mathrm{K}+\mathrm{Na})+0.024$ $(\alpha$-amino nitrogen $)+0.48$, where the content of $\mathrm{K}, \mathrm{Na}$ and $\alpha$-amino nitrogen are given in mmol kg-1 of pulp [29]; refined sugar content $(\%)=$ sucrose content $(\%)$-sugar yield losses $(\%)$; sugar productivity $(\%)=$ refined sugar content $(\%) /$ sugar content $(\%) \times 100$; and alkalinity coefficient $\mathrm{W}_{\mathrm{A}}=\left(\right.$ content of $\mathrm{K}\left(\mathrm{mmol} \mathrm{kg}^{-1}\right)+$ content of $\left.\mathrm{Na}\left(\mathrm{mmol} \mathrm{kg}^{-1}\right)\right) /$ content of $\alpha$-amino nitrogen $\left(\mathrm{mmol} \mathrm{kg}^{-1}\right)$ [30].

Analysis of variance was applied for the evaluation of the effects of the studied factors and their interaction. Multiple comparisons of means using Tukey's HSD procedure were performed for separation of the homogenous groups of the means. The analyses were conducted using Statistica 13 program (TIBCO Software Inc.) at significance level 0.05. Basic statistical parameters, i.e., range, standard deviation (SD) and coefficient of variation $(\mathrm{CV})$, were calculated.

\section{Results}

Results of the analysis of variance proved a significant effect of the year for almost all studied traits (Table 3). The only exception was fresh plant biomass. A significant effect of the treatment was observed for most of the studied traits (exceptions: harvest index, foliage coefficient and fresh mass of the leaves of the plant). A significant interaction (year $\times$ treatment) was observed for most of the traits, which means that the effect of the treatment was dependent on the year. The exceptions were the yield of roots, yield of roots and leaves, biological yield of sugar, pure sugar yield, fresh mass of the leaves of the plant and fresh plant biomass. Plant density during harvest was not significantly different between particular treatments and ranged from 88.8 to 92.0 thousand plants ha ${ }^{-1}$ (Table 4). All treatments with silicon foliar application contributed to a significant increase in the root yield (10.7-11.7\%) compared to the control object, but their effect was not significantly different. A significant increase in the yield of leaves was observed only in treatment no. 2. A significant increase in the biological yield of sugar was found in treatments no. 2 (by $12.2 \%$ ) and 3 (by 11.6\%), and a slightly smaller, but statistically insignificant increase, in 
treatment no. 1 (by $8.4 \%$ ) was observed. It was not significantly different in the case of pure sugar yield, where the gains amounted to $11.8 \%, 11.3 \%$ and $7.2 \%$, respectively.

Table 3. Results based on analysis of variance (ANOVA) presenting effects ( $p$-values) of the factors and their interaction on the yield, the technological quality of the roots and traits of sugar beet plants (2017-2019).

\begin{tabular}{|c|c|c|c|}
\hline \multirow{2}{*}{ Trait } & \multicolumn{3}{|c|}{ Effect ( $p$-Value) } \\
\hline & Year & Treatmant & Year $\times$ Treatment \\
\hline Plant density at harvest, thousand plants ha ${ }^{-1}$ & 0.001 & 0.639 & $<0.001$ \\
\hline Yield of roots, $\mathrm{tha}^{-1}$ & $<0.001$ & 0.036 & 0.697 \\
\hline Yield of leaves, $\mathrm{t}$ ha ${ }^{-1}$ & $<0.001$ & 0.050 & 0.023 \\
\hline Yield of roots and leaves, $\mathrm{t} \mathrm{ha}^{-1}$ & 0.084 & 0.029 & 0.439 \\
\hline Biological yield of sugar, $\mathrm{t} \mathrm{ha}^{-1}$ & $<0.001$ & 0.031 & 0.447 \\
\hline Pure sugar yield, $\mathrm{t} \mathrm{ha}^{-1}$ & $<0.001$ & 0.076 & 0.429 \\
\hline Harvest Index & $<0.001$ & 0.799 & 0.024 \\
\hline Foliage coefficient & $<0.001$ & 0.727 & 0.028 \\
\hline Content of sucrose in roots, $\%$ & $<0.001$ & $<0.001$ & 0.001 \\
\hline The content of $\alpha$-amino nitrogen in the roots, $\mathrm{mmol} \mathrm{kg}^{-1}$ & $<0.001$ & 0.015 & 0.023 \\
\hline Potassium content in the roots, $\mathrm{mmol} \mathrm{kg}^{-1}$ & 0.026 & 0.011 & 0.006 \\
\hline Sodium content in the roots, $\mathrm{mmol} \mathrm{kg}^{-1}$ & 0.015 & 0.045 & 0.014 \\
\hline Standard molasses losses, $\%$ & $<0.001$ & 0.015 & 0.017 \\
\hline Sugar yield losses, $\%$ & $<0.001$ & 0.015 & 0.017 \\
\hline Refined sugar content, \% & $<0.001$ & $<0.001$ & 0.001 \\
\hline Sugar productivity, \% & $<0.001$ & 0.001 & 0.002 \\
\hline Alkalinity coefficient & $<0.001$ & $<0.001$ & 0.003 \\
\hline Fresh root mass, $\mathrm{kg}$ & $<0.001$ & 0.045 & 0.001 \\
\hline Fresh mass of the leaves of the plant, $\mathrm{kg}$ & $<0.001$ & 0.292 & 0.935 \\
\hline Fresh plant biomass, $\mathrm{kg}$ & 0.683 & 0.038 & 0.084 \\
\hline
\end{tabular}

Table 4. The influence of various forms of silicon on the yield, the technological quality of the roots and the traits of sugar beet plants (2017-2019).

\begin{tabular}{|c|c|c|c|c|}
\hline \multirow{2}{*}{ Trait } & \multicolumn{4}{|c|}{ Treatment } \\
\hline & 0 & 1 & 2 & 3 \\
\hline Plant density at harvest, thousand plants ha ${ }^{-1}$ & $89.12 \mathrm{a}^{1}$ & $92.01 \mathrm{a}$ & 90.39 a & $88.77 \mathrm{a}$ \\
\hline Yield of roots, $\mathrm{tha}^{-1}$ & $73.09 \mathrm{a}$ & $81.14 \mathrm{~b}$ & $80.94 b$ & $81.64 \mathrm{~b}$ \\
\hline Yield of leaves, $\mathrm{t}$ ha ${ }^{-1}$ & $45.05 \mathrm{a}$ & $49.66 \mathrm{ab}$ & $52.43 \mathrm{~b}$ & $49.38 \mathrm{ab}$ \\
\hline Yield of roots and leaves, $\mathrm{tha}^{-1}$ & 118.14 a & $130.80 \mathrm{~b}$ & $133.37 \mathrm{~b}$ & $131.02 \mathrm{~b}$ \\
\hline Biological yield of sugar, $\mathrm{t} \mathrm{ha}^{-1}$ & $13.06 \mathrm{a}$ & $14.16 \mathrm{ab}$ & $14.65 \mathrm{~b}$ & $14.58 \mathrm{~b}$ \\
\hline Pure sugar yield, $\mathrm{t} \mathrm{ha}^{-1}$ & $11.57 \mathrm{a}$ & $12.40 \mathrm{ab}$ & $12.94 \mathrm{~b}$ & $12.88 \mathrm{~b}$ \\
\hline Harvest Index & $0.616 \mathrm{a}$ & $0.621 \mathrm{a}$ & $0.607 \mathrm{a}$ & $0.621 \mathrm{a}$ \\
\hline Foliage coefficient & $0.656 \mathrm{a}$ & $0.653 \mathrm{a}$ & $0.684 \mathrm{a}$ & $0.628 \mathrm{a}$ \\
\hline Content of sucrose in roots, $\%$ & $17.65 \mathrm{~b}$ & $17.28 \mathrm{a}$ & $17.96 \mathrm{c}$ & $17.58 \mathrm{~b}$ \\
\hline The content of $\alpha$-amino nitrogen in the roots, $\mathrm{mmol} \mathrm{kg}^{-1}$ & $24.65 \mathrm{a}$ & $27.90 \mathrm{~b}$ & $25.68 \mathrm{ab}$ & $23.92 \mathrm{a}$ \\
\hline Potassium content in the roots, $\mathrm{mmol} \mathrm{kg}^{-1}$ & $29.45 \mathrm{a}$ & $32.10 \mathrm{~b}$ & $30.07 \mathrm{a}$ & $32.08 \mathrm{~b}$ \\
\hline Sodium content in the roots, $\mathrm{mmol} \mathrm{kg}^{-1}$ & $2.72 \mathrm{a}$ & $3.48 \mathrm{~b}$ & $2.63 \mathrm{a}$ & $2.83 \mathrm{ab}$ \\
\hline Standard molasses losses, $\%$ & $1.46 \mathrm{a}$ & $1.58 \mathrm{~b}$ & $1.49 \mathrm{a}$ & $1.47 \mathrm{a}$ \\
\hline Sugar yield losses, \% & $2.06 \mathrm{a}$ & $2.18 \mathrm{~b}$ & $2.09 \mathrm{a}$ & $2.07 \mathrm{a}$ \\
\hline Refined sugar content, $\%$ & $15.59 \mathrm{bc}$ & $15.10 \mathrm{a}$ & $15.87 \mathrm{c}$ & $15.51 \mathrm{~b}$ \\
\hline Sugar productivity, \% & $88.23 \mathrm{~b}$ & $87.35 \mathrm{a}$ & $88.33 \mathrm{~b}$ & $88.16 \mathrm{~b}$ \\
\hline Alkalinity coefficient & $1.32 \mathrm{a}$ & $1.30 \mathrm{a}$ & $1.33 \mathrm{a}$ & $1.50 \mathrm{~b}$ \\
\hline Fresh root mass, $\mathrm{kg}$ & $0.820 \mathrm{a}$ & $0.895 \mathrm{ab}$ & $0.897 \mathrm{ab}$ & $0.923 \mathrm{~b}$ \\
\hline Fresh mass of the leaves of the plant, $\mathrm{kg}$ & $0.512 \mathrm{a}$ & $0.539 \mathrm{a}$ & $0.580 \mathrm{a}$ & $0.571 \mathrm{a}$ \\
\hline Fresh plant biomass, $\mathrm{kg}$ & $1.332 \mathrm{a}$ & $1.434 \mathrm{~b}$ & $1.477 \mathrm{~b}$ & $1.494 \mathrm{~b}$ \\
\hline
\end{tabular}

${ }^{1}$ The same letters within rows indicate a lack of significant differences between means at $\alpha=0.05$. 
There were no significant differences in the values of the Harvest Index and foliage coefficient.

The impact of the assessed foliar applications on the sucrose content in sugar beet roots was varied. Treatment no. 1 significantly increased it, and treatment no. 2 significantly decreased it compared to the control object. On the other hand, treatment no. 3 had no significant effect.

The effect of the tested treatments on the content of molasses-forming components in the roots was also diversified.

The content of $\alpha$-amino nitrogen in relation to treatment no. 0 was significantly increased only by treatment no. 1, potassium content for treatment no. 1 and 3 and sodium for treatment no. 1 .

Treatment no. 1 significantly increased the standard of molasses losses and sugar yield losses and decreased refined sugar content and sugar productivity. On the other hand, treatment no. 2 significantly increased refined sugar content, and treatment no. 3 increased alkalinity coefficient.

The differences in the root yield, biological sugar yield and pure sugar yield between the treatments with foliar application and the control treatment in individual years were insignificant (Figure 2). The sucrose content in the roots in 2017 for treatment no. 3 was lower than for treatment no. 0 (similarly to treatment no. 1 in 2019). In 2018, treatment no. 2 and 3 showed a significantly higher sucrose content compared to the control object.

Among the examined traits, the highest variability was found in the foliage coefficient $(\mathrm{CV}=37.4 \%)$, and the lowest variability was found in the sugar productivity $(\mathrm{CV}=1.38 \%)$ (Table 5).

Table 5. Descriptive statistics for all experiments with sugar beet (2017-2019).

\begin{tabular}{|c|c|c|c|c|c|}
\hline Trait & Mean & Minimum & Maximum & $\begin{array}{c}\text { Standard Deviation } \\
\text { (SD) }\end{array}$ & $\begin{array}{c}\text { Coefficient of } \\
\text { Variation }(\mathrm{CV}), \%\end{array}$ \\
\hline Plant density at harvest, thousand plants ha ${ }^{-1}$ & 90.08 & 69.44 & 105.56 & 9.64 & 10.70 \\
\hline Yield of roots, $\mathrm{t} \mathrm{ha}^{-1}$ & 79.21 & 52.22 & 103.47 & 14.45 & 18.25 \\
\hline Yield of leaves, $\mathrm{t}$ ha ${ }^{-1}$ & 49.13 & 29.65 & 79.86 & 11.77 & 23.95 \\
\hline Yield of roots and leaves, $\mathrm{t} \mathrm{ha}^{-1}$ & 128.34 & 98,92 & 157,78 & 14,37 & 11,20 \\
\hline Biological yield of sugar, $\mathrm{t} \mathrm{ha}^{-1}$ & 14.11 & 8.14 & 18.85 & 3.30 & 23.40 \\
\hline Pure sugar yield, $\mathrm{t} \mathrm{ha}^{-1}$ & 12.45 & 7.00 & 16.76 & 2.99 & 24.03 \\
\hline Harvest Index & 0.616 & 0.471 & 0.742 & 0.084 & 13.71 \\
\hline Foliage coefficient & 0.655 & 0.348 & 1.123 & 0.245 & 37.42 \\
\hline Content of sucrose in roots, $\%$ & 17.62 & 15.42 & 19.23 & 1.27 & 7.21 \\
\hline 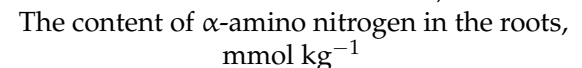 & 25.54 & 17.70 & 39.00 & 4.91 & 19.23 \\
\hline Potassium content in the roots, $\mathrm{mmol} \mathrm{kg}^{-1}$ & 30.93 & 24.40 & 36.20 & 2.97 & 9.62 \\
\hline Sodium content in the roots, $\mathrm{mmol} \mathrm{kg}-1$ & 2.92 & 0.40 & 4.80 & 0.98 & 33.69 \\
\hline Standard molasses losses, $\%$ & 1.50 & 1.30 & 1.84 & 0.14 & 9.07 \\
\hline Sugar yield losses, $\%$ & 2.10 & 1.90 & 2.44 & 0.14 & 6.48 \\
\hline Refined sugar content, $\%$ & 15.52 & 13.27 & 17.31 & 1.29 & 8.32 \\
\hline Sugar productivity, $\%$ & 88.02 & 86.03 & 89.99 & 1.21 & 1.38 \\
\hline Alkalinity coefficient & 1.36 & 0.91 & 2.01 & 0.24 & 17.46 \\
\hline Fresh root mass, $\mathrm{kg}$ & 0.884 & 0.559 & 1.227 & 0.159 & 17.96 \\
\hline The fresh mass of the leaves of the plant, $\mathrm{kg}$ & 0.551 & 0.314 & 0.892 & 0.142 & 25.83 \\
\hline Fresh plant biomass, $\mathrm{kg}$ & 1.435 & 1.074 & 1.803 & 0.173 & 12.04 \\
\hline
\end{tabular}



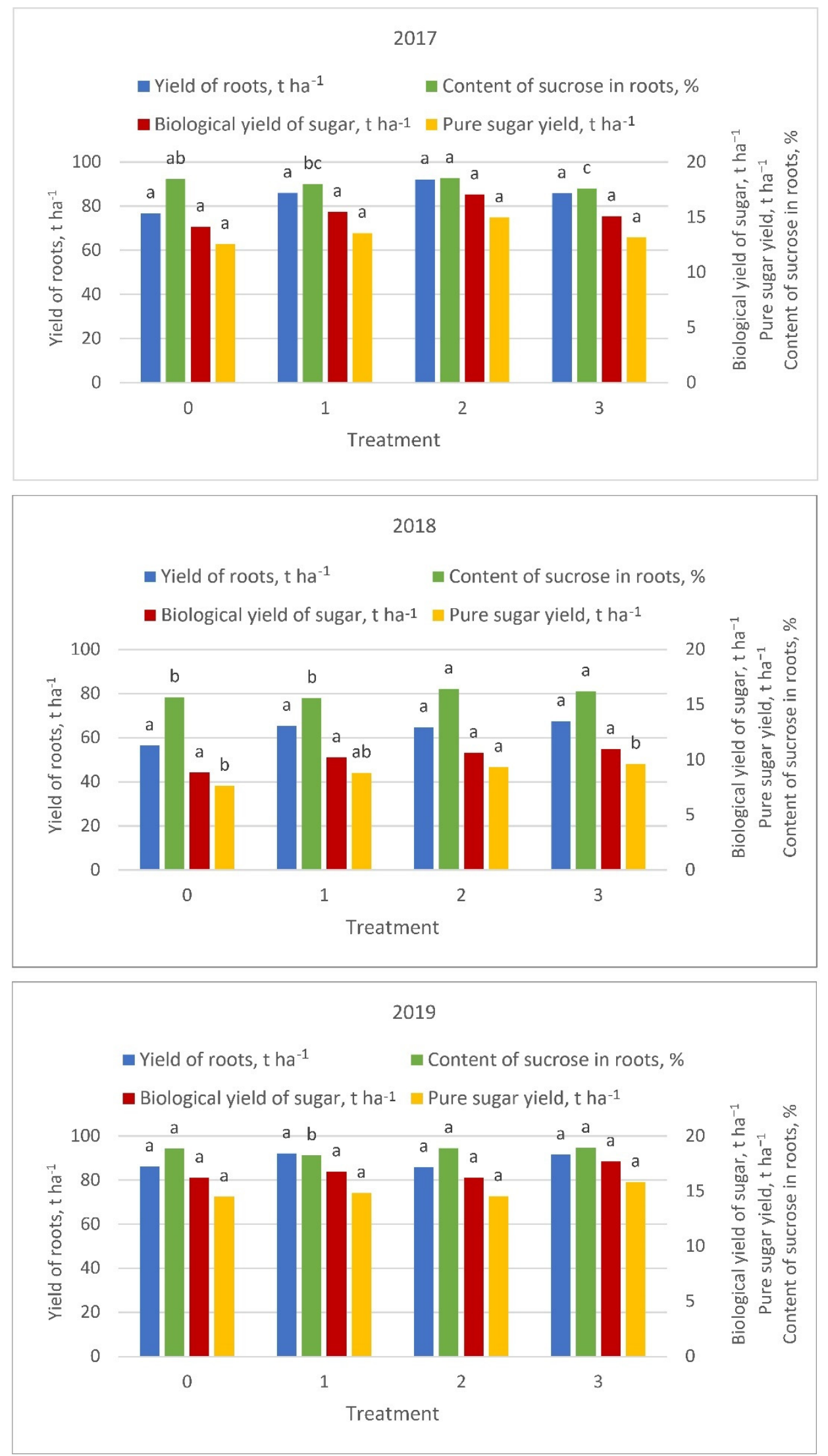

Figure 2. Means for the treatments of foliar fertilization of silicon of yield of roots, sugar yield and sucrose content in years 2017-2019 and their statistical comparisons. (The same letters for the columns in the same colour indicate homogenous groups of the means at $\alpha=0.05$.). 


\section{Discussion}

The weather conditions have a strong influence on the sugar beet yield [31-35]. In our research, the highest yields of roots and sugar were obtained in 2017 and 2019. This was definitely lower in 2018, which was characterized by a higher temperature each month during the vegetation period in comparison to the multi-year average.

The length of the growing season is determined by the sowing and harvesting dates. The sowing date depends on the course of weather conditions in early spring. In our research, the length of the growing season was 195 days in 2017, 178 days in 2018 and 180 days in 2019. The variation in the harvest date was caused by the weather conditions in this period.

The final trait in sugar beet production is pure sugar yield. It depends primarily on the root yield, and the effect of the sucrose content in the roots (positive effect) and molassesforming components (negative effect) is much smaller. With a similar plant density during harvesting, the root yield and, consequently, the pure sugar yield are determined by the fresh weight of the root $[35,36]$. Our research confirmed the beneficial effect of foliar application of the tested silicon forms on fresh root mass and root yield.

In the available literature, there are only a few publications on the effects of the foliar application of silicon in the cultivation of sugar beet. The increases in the yield of sugar beet roots obtained in our research as a result of the foliar application of silicon-containing products were lower than those obtained in previous studies (Table 6). Only some studies on production fields did not increase the root yield after the foliar application of marine calcite [7]. The increase in the yield after the application of calcium silicate, obtained in the authors' research, contradicts some opinions that silicates applied on leaves only reduce infections and have no influence on the yield [37]. In the case of the biological yield of sugar and pure sugar yield, the observed gains were lower than in previous studies with some exceptions. The beneficial effect of nano-Si on the increase drought tolerance of sugar beet depends on the selection of an appropriate concentration, as too high a concentration may be toxic for plants subjected to severe drought stress [38]. Previous studies have shown that the foliar application of various forms of silicon was profitable for sugar beet producers $[39,40]$.

Table 6. Results of studies on foliar application of various forms of silicon in the cultivation of sugar beet.

\begin{tabular}{|c|c|c|c|c|c|}
\hline \multirow{3}{*}{$\begin{array}{c}\text { Form of Silicon Applied as a } \\
\text { Foliar Application }\end{array}$} & \multicolumn{4}{|c|}{ Maximum Difference in Control Ratio (No Foliar Application) } & \multirow{3}{*}{ References } \\
\hline & \multicolumn{3}{|c|}{$\%$} & p.p. & \\
\hline & Yield of Roots & $\begin{array}{l}\text { Biological Yield } \\
\text { of Sugar }\end{array}$ & Pure Sugar Yield & Content of Sucrose & \\
\hline \multirow{5}{*}{ Marine calcite } & 0.0 & +2.7 & +4.9 & +0.5 & [7] \\
\hline & +12.0 & +9.7 & +8.6 & -0.6 & [4] \\
\hline & +14.6 & +21.8 & +17.8 & +0.6 & [5] \\
\hline & +16.2 & +18.1 & +17.7 & -0.6 & [8] \\
\hline & +21.8 & +24.8 & +25.2 & +0.2 & [6] \\
\hline $\begin{array}{l}\text { Orthosilicic acid stabilized with choline } \\
\text { with the addition of calcium }\end{array}$ & +25.1 & +23.2 & +22.2 & -0.7 & [8] \\
\hline Mixture of orthosilicic and polysilicic & +15.9 & +15.7 & +15.6 & +0.2 & [8] \\
\hline acids with the addition of iron & +18.9 & +16.4 & +14.1 & -0.4 & [4] \\
\hline Potassium silicate & +20.4 & +21.9 & +23.3 & +0.5 & [9] \\
\hline \multirow{2}{*}{ Silica nanoparticles } & +6.5 & +6.2 & +6.8 & -0.1 & [11] \\
\hline & +12.8 & +19.6 & +19.6 & +1.1 & [10] \\
\hline
\end{tabular}

A crop with a production technology similar to that of sugar beet is potato. In the case of potato, most studies proved a positive effect of the foliar application of various forms of silicon on the tuber yield, and the dry matter content in tubers was observed (Table 7). 
Table 7. Results of studies on foliar application of various forms of silicon in the cultivation of potato.

\begin{tabular}{|c|c|c|c|c|}
\hline \multirow{3}{*}{ Form of Silicon Applied as a Foliar Application } & \multicolumn{3}{|c|}{ Maximum Difference in Control Ratio (No Foliar Application) } & \multirow{3}{*}{ References } \\
\hline & \multicolumn{2}{|c|}{$\%$} & \multirow{2}{*}{$\begin{array}{c}p . p . \\
\text { Content of Dry Matter }\end{array}$} & \\
\hline & Yield of Tubers & $\begin{array}{l}\text { Commercial Yield } \\
\text { of Tubers }\end{array}$ & & \\
\hline Marine calcite & +9.0 & +11.0 & No data & [41] \\
\hline $\begin{array}{l}\text { Orthosilicic acid stabilized with choline with the } \\
\text { addition of calcium }\end{array}$ & -13.6 & No data & -0.7 & [42] \\
\hline Orthosilicic acid + microelements $(\mathrm{Cu}, \mathrm{Zn}, \mathrm{B}, \mathrm{Mo})$ & +10.8 & No data & No data & [43] \\
\hline Orthosilicic acid + microelements $(\mathrm{Cu}, \mathrm{Zn}, \mathrm{B}, \mathrm{Mo})$ & +12.9 & No data & +0.5 & [44] \\
\hline Orthosilicic acid & +21.0 & +18.3 & +0.1 & [45] \\
\hline Oligomeric silicic acid and boric acid & +6.5 & No data & No data & [46] \\
\hline Silicic acid (type of SA is not mentioned) & +12.8 & No data & No data & [47] \\
\hline Orthosilicic and disilicic acid & $\begin{array}{c}\text { similar to } \\
\text { well-watered potato } \\
\text { plants (water-stress) }\end{array}$ & No data & No data & [48] \\
\hline
\end{tabular}

The main feature of the technological quality of sugar beet roots is the sucrose content. In our research, this increased after the foliar application of orthosilicic acid, decreased after using a mixture of orthosilicic and polysilicic acids and did not change significantly as a result of the use of calcium silicate. This is confirmed by previous research results, in which the effect of the foliar application of silicon-containing products was also varied (Table 6).

Among the molasses-forming components, the most harmful is $\alpha$-amino nitrogen, which limits the extraction of sugar from the roots the most and increases its losses. In our research, only the foliar application of orthosilicic acid resulted in a significant increase in the content of this component. In previous studies, the effect of the foliar application of silicon, regardless of its form and the content of other components in foliar fertilizers and stimulators, caused slight changes in the content of $\alpha$-amino nitrogen in sugar beet roots.

The varied influence of the foliar application of silicon could result from the different course of weather conditions during the growing season in individual years of the study. In general, the less favourable they were to plant growth and development, the more pronounced the effects were.

The results of this study allowed us to reject the research hypothesis that various forms of silicon applied in foliar application have a different effect on the yield of roots, their technological quality and biological sugar yield and pure sugar yield.

\section{Conclusions}

\section{Practical Implications of this Study}

The conclusion is that for agricultural practice, the use of all three forms of silicon tested in the experiments can be recommended. It is impossible to indicate which of the tested forms of silicon has the most beneficial effect. This is useful for farmers as it guarantees a wide range of products that can be used for application.

The presented research results prove that the foliar application of silicon, regardless of its form, has a beneficial effect on the root yield, biological sugar yield and pure sugar yield. The effect of the application of silicon depends on weather conditions in years of the study as well on the interaction between weather conditions and the studied treatments.

Further research should focus on determining the optimal date of foliar application of the products with silicon depending on the weather conditions. Unfortunately, such research is difficult to perform in field conditions; it can be performed under controlled laboratory conditions, but the results thus obtained are often not confirmed in field conditions. 
Author Contributions: Conceptualization, A.A.; formal analysis, A.A.; investigation, A.A.; methodology, A.A.; supervision, A.A.; visualization, D.G.; writing-original draft, A.A. and D.G.; writingreview and editing, A.A. and D.G. All authors have read and agreed to the published version of the manuscript.

Funding: This research received no external funding.

Institutional Review Board Statement: Not applicable.

Informed Consent Statement: Not applicable.

Data Availability Statement: The data presented in this study are available on request from the corresponding author. The data are not publicly available due to ongoing unpublished research.

Acknowledgments: The authors would like to express their sincere gratitude to KWS Poland Breeding Company Ltd., Poznań and Kutno Sugar Beet Breeding Company Ltd., Straszków, Poland for assistance in conducting the experiments.

Conflicts of Interest: The authors declare no conflict of interest.

\section{References}

1. FAO. Food and Agriculture Data. Available online: http://www.fao.org/faostat/en/\#data/QC (accessed on 14 June 2021).

2. European Commision. Communication from the commission to the European Parliament, the Council, the European Economic and Social Committee and the Committee of the Regions. In A Farm to Fork Strategy for a Fair, Healthy and Environmentally-Friendly Food System; European Commision: Brussels, Belgium, 2020; p. 23.

3. Artyszak, A. Effect of silicon fertilization on crop yield quantity and quality-A literature review in Europe. Plants 2018, 7, 54. [CrossRef]

4. Artyszak, A. Possibilities of Using Silicon for Foliar Fertilization of Sugar Beet; Wieś Jutra: Warsaw, Poland, 2017; p. 128. (In Polish)

5. Artyszak, A.; Gozdowski, D.; Kucińska, K. The effect of foliar fertilization with marine calcite in sugar beet. Plant Soil Environ. 2014, 60, 413-417. [CrossRef]

6. Artyszak, A.; Gozdowski, D.; Kucińska, K. The effect of calcium and silicon foliar fertilization in sugar beet. Sugar Tech 2016, 18, 109-114. [CrossRef]

7. Artyszak, A.; Kucińska, K. Silicon nutrition and crop improvement: Recent advances and future perspective. In Silicon in Plants; Tripathi, D.K., Singh, V.P., Ahmad, P., Chauhan, D.K., Prasad, S.M., Eds.; CRC Press Taylor \& Francis Group Boca Raton: London, UK; New York, NY, USA, 2016; pp. 297-319.

8. Artyszak, A.; Gozdowski, D.; Kucińska, K. The effect of silicon foliar fertilization in sugar beet-Beta vulgaris (L.) ssp. vulgaris conv. crassa (Alef.) prov. altissima (Döll). Turk. J. Field. Crops 2015, 20, 115-119.

9. Artyszak, A.; Gozdowski, D.; Siuda, A. Effect of the application date of fertilizer containing silicon and potassium on the yield and technological quality of sugar beet roots. Plants 2021, 10, 370. [CrossRef] [PubMed]

10. Hřivna, L.; Hernandez Kong, J.; Machálková, L.; Burešová, I.; Sapáková, E.; Kučerová, J.; Šottníková, V. Vliv mimokořenové výživy draslíkem a křemíkem na výnos a kvalitu cukrovky v nestandardních povětrnostních podmínkách roku 2014 a 2015. Listy Cukrov. Repar. 2017, 133, 182-187. (In Czech)

11. Urban, J.; Pulkrabek, J. Navýšení výnosu a jakosti cukrové řepy pomocí listové výživy a biologicky aktivních látek. Listy Cukrov. Repar. 2018, 134, 188-194. (In Czech)

12. IUSS Working Group WRB. World Reference Base for Soil Resources 2014. International Soil Classification System for Naming Soils and Creating Legends for Soil Maps; Update 2015; World Soil Resources Raport 106; FAO: Rome, Italy, 2015.

13. PKN. PN-ISO 10390:1997. Soil Quality—pH Determination; Polish Committee for Standardization: Warsaw, Poland, 1997. (In Polish)

14. Research Procedure of the Regional Agrochemical Station in Warsaw, No. PB 01 ed.; Regional Agrochemical Station: Warsaw, Poland, 2009. (In Polish)

15. Research Procedure of the Regional Agrochemical Station in Warsaw, No. PB 46 ed.; Regional Agrochemical Station: Warsaw, Poland, 2017. (In Polish)

16. PKN. Polish Standard PN-R-04023:1996. Agro-Chemical Analysis of Soil-Determination of Available Phosphorus Content in Mineral Soils; Polish Committee for Standardization: Warsaw, Poland, 1996. (In Polish)

17. PKN. Polish Standard PN-R-04022:1996/Az1:2002. Agro-Chemical Analysis of Soil_Determination of Available Potassium Content in Mineral Soils; Polish Committee for Standardization: Warsaw, Poland, 1996. (In Polish)

18. PKN. Polish Standard PN-R-04020:1994/Az1:2004. Agro-Chemical Analysis of Soil_Determination of Available Magnesium Content in Mineral Soils; Polish Committee for Standardization: Warsaw, Poland, 1994. (In Polish)

19. PKN. Polish Standard PN-93/R-04018. Agro-Chemical Analysis of Soil. Determination of Available Boron; Polish Committee for Standardization: Warsaw, Poland, 1993. (In Polish)

20. PKN. Polish Standard PN-92/R-04017. Agro-Chemical Analysis of Soil. Determination of Available Copper; Polish Committee for Standardization: Warsaw, Poland, 1991. (In Polish) 
21. PKN. Polish Standard PN-R-04021: 1994. Agro-Chemical Analysis of Soil. Determination of Available Iron; Polish Committee for Standardization: Warsaw, Poland, 1994. (In Polish)

22. PKN. Polish Standard PN-93/R-04019. Agro-Chemical Analysis of Soil. Determination of Available Manganese; Polish Committee for Standardization: Warsaw, Poland, 1993. (In Polish)

23. PKN. Polish Standard PN-92/R-04016. Agro-Chemical Analysis of Soil. Determination of Available Zinc; Polish Committee for Standardization: Warsaw, Poland, 1992. (In Polish)

24. COBORU. Lista Opisowa Roślin Rolniczych 2015; Burak Cukrowy, Ziemniak, Oleiste, Pastewne: Słupia Wielka, Polska, 2015. (In Polish)

25. PKN. Polish Standard PN-R-74458. Sugar Beet Roots; Polish Committee for Standardization: Warsaw, Poland, 1999. (In Polish)

26. Hassan, I.; Mostafa, S. Influence of sugar beet nitrogen content on quality and efficiency of sugar extraction. J. Food Dairy Sci. 2018, 9, 111-116. [CrossRef]

27. ICUMSA. International Commission for Uniform Methods of Sugar Analysis. 1994. Available online: http://www.icumsa.org (accessed on 15 April 2021).

28. Burba, M.; Georgi, B. Die fluorometrische Bestimmung der Aminosaüren in Zuckerrüben und Zuckerfabriksprodukten mit Fluoreszamin und o-Phtalaldehyd. Zuckerindustrie 1976, 26, 322-328. (In German)

29. Buchholz, K.; Märländer, B.; Puke, H.; Glattkowski, H.; Thielecke, K. Neubewertung des technischen Wertes von Zuckerrben. Zuckerindustrie 1995, 120, 113-121. (In German)

30. Trzebiński, J. Ocena wydajności cukru z korzeni. In Produkcja Buraka Cukrowego; Gutmański, I., Ed.; PWRiL: Poznań, Poland, 1991; pp. 591-597. (In Polish)

31. Dzieżyc, J.; Nowak, L.; Panek, K. Dekadowe wskaźniki potrzeb opadowych roślin uprawnych w Polsce. Zesz. Probl. Post. Nauk Roln. 1987, 314, 11-32. (In Polish)

32. Demidowicz, G.; Doroszewski, A.; Górski, T. Wpływ niedoboru opadów na straty w produkcji ziemniaka i buraka cukrowego. Zesz. Probl. Post. Nauk Roln. 1996, 438, 43-52. (In Polish)

33. Chmura, K.; Chylińska, E.; Dmowski, Z.; Nowak, L. Rola czynnika wodnego w kształtowaniu plonu wybranych roślin polowych. IiETW 2009, 9, 33-44. (In Polish)

34. Dmowski, Z.; Dzieżyc, H.; Chmura, K. Porównanie potrzeb wodnych buraka cukrowego określonych przez sumę oraz liczbę dni z opadem. IiETW 2011, 5, 183-192. (In Polish)

35. Artyszak, A. Agrotechniczne oraz Siedliskowe Uwarunkowania Plonowania i Zdrowotności Korzeni Buraka Cukrowego; Rozprawy Naukowe i Monografie. Wyd; SGGW Warszawa: Warsaw, Poland, 2012; p. 128. (In Polish)

36. Wyszyński, Z. Zmienność cech Roślin Buraka Cukrowego w Łanie oraz Plonowanie i Jakość Korzeni pod Wpływem Czynników ŚrodowiskowoAgrotechnicznych; Rozprawy Naukowe i Monografie 398. Wyd; SGGW Warszawa: Warsaw, Poland, 2003; p. 136. (In Polish)

37. Laane, H.-M. The effects of foliar sprays with different silicon compounds. Plants 2018, 7, 45. [CrossRef]

38. Namjoyan, S.; Sorooshzadeh, A.; Rajabi, A.; Aghaalikhani, M. Nano-silicon protects sugar beet plants against water deficit stress by improving the antioxidant systems and compatible solutes. Acta Physiol. Plant. 2020, 42, 1-16. [CrossRef]

39. Artyszak, A.; Klarzyńska, E.; Litwińczuk-Bis, M.; Siuda, A. Profitability of sugar beet foliar nutrition with silicon. Ann. PAAAE 2019, 21, 7-13. [CrossRef]

40. Litwińczuk-Bis, M.; Siuda, A.; Artyszak, A. The economic effects of foliar fertilization of sugar beet with marine calcite. Ann. PAAAE 2019, 21, 188-195. [CrossRef]

41. Trawczyński, C. Wpływ dolistnego nawożenia preparatem Herbagreen na plonowanie ziemniaków. Ziemn. Polski 2013, 2, 29-33. (In Polish)

42. Wróbel, S. Wpływ nawożenia ziemniaka odmiany Jelly dolistnymi preparatami YaraVita Ziemniak oraz Actisil na plon i cechy jego jakości. Biul. IHAR 2012, 266, 295-305. (In Polish)

43. Trawczyński, C. The effect of foliar preparation with silicon on the yield and quality of potato tubers in compared to selected biostymulators. Fragm. Agron. 2018, 35, 113-122. [CrossRef]

44. Trawczyński, C. Ocena plonowania i jakości bulw po aplikacji dolistnej krzemu i mikroelementów. Agron. Sci. 2021, LXXVI, 9-20. [CrossRef]

45. Soratto, R.P.; Fernandes, A.N.; Crusciol, C.A.C.; de Souza-Schlick, G.D. Yield, tuber quality, and disease incidence on potato crop as affected by silicon leaf application. Pesq. Agropec. Bras. 2012, 47, 1000-1006. [CrossRef]

46. Kamp, L. Gebruik van Siliciumzuur in de akkerbouw. In Silicon Solutions-Helping Plants to Help Themselves; Bent, E., Ed.; Sestante: Bergamo, Italy, 2014; p. 37.

47. Da Silva, V.F.; Morales, J.C.; Melo, B.A. Influence of silicon on the development, productivity and infestation by insect pest in potato crop. Ciênc. Agrotec. Lavras 2010, 34, 1465-1469. [CrossRef]

48. Pilon, C.; Soratto, R.P.; Broetto, F.; Fernandes, A.M. Foliar or soil applications of silicon alleviate water-deficit stress of potato plants. Agron. J. 2014, 106, 2325-2334. [CrossRef] 